\title{
LA FORMACIÓN DEL PROFESORADO Y LA MEJORA DE LA EDUCACIÓN*
}

ANDREa Coelho Lastória ${ }^{* *}$

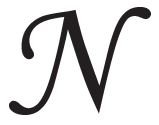

este livro estão reunidos trabalhos de alguns renomados pesquisadores europeus que investigam sobre formação inicial e continuada de professores. Esta temática vem sendo tomada como uma questão central para se rediscutir as políticas e as práticas do sistema educativo na sociedade atual. Considerada, ao mesmo tempo, o caminho mais promissor para a superação da crise educacional e o mais difícil de ser resolvido.

Os textos apresentados são provenientes do Seminário sobre Formação de Professores, organizado pela Universidad Internacional Menéndez Pelayo, em Santander - Espanha, no ano de 2005. No livro, nove professores expóem as realidades vivenciadas nas comunidades espanholas e em mais dois países europeus, apontando sugestões importantes para a melhoria do processo formativo como um todo.

A obra é iniciada com a apresentação da conselheira educacional da comunidade espanhola de Cantábria (subsidiária da publicação), seguida de uma rica produção do professor Juan Manuel Escudero Muñoz sobre a formação de professores como garantia do direito a uma boa educação para todos.

Os trabalhos estão agrupados em duas seções. Na primeira, denominada "Reformas y políticas de la formación del profesorado", encontra-se um detalhado texto do professor Ewald Terhart, da Universidad de Munster, sobre os principais problemas da formação de

Resenha do livro organizado por Juan Manuel Escudero Muñoz e Alberto Luis Gómez (Octaedro: Barcelona, 2006. 340p.)

* Doutora em Educação e professora do Departamento de Psicologia e Educação da Faculdade de Filosofia, Ciências e Letras da Universidade de São Paulo (USP). E-mail: lastoria@ffclrp.usp.br 
professores na Alemanha. Questionamentos sobre os efeitos positivos desta formação são levantados juntamente com as dúvidas em torno da chamada "europeização" da formação de professores.

Em seguida, o caso inglês é abordado a partir das reflexões dos professores Jesús Romero Morante e Alberto Luis Gómez, ambos da Universidad de Cantábria, sobre a reestruturação dos sistemas educativos e mudanças na formação inicial. Abordam as reformas educativas inglesas desde o governo de Margareth Thatcher até Tony Blair, as políticas de formação inicial durante as décadas de 1980/1990 e a ressignificação da profissão docente no cenário europeu atual.

O trabalho do professor Antonio Bolívar, da Universidad de Granada, oferece um panorama da formação inicial dos professores e o desenvolvimento das instituições formadoras na Espanha. Perpassa a questão da formação para a educação infantil, para os anos iniciais e finais do ensino fundamental. Ressalta as crises encontradas pelos professores desde a etapa de formação inicial até a vida profissional, as problemáticas que envolvem as instituições de ensino superior que formam professores, as relaçôes entre as universidades e escolas, entre outros.

A professora Maria de Lourdes Montero, da Universidade de Santiago de Compostela, também aborda o contexto espanhol, porém focaliza seu discurso nas instituições de formação continuada, nos formadores e nas políticas de formação do estado das várias Comunidades Autônomas.

A segunda seção da obra recebe o nome de "La construcción de la profesionalidad docente". Nela encontra-se o texto do professor José Maria Rozada, da Universidad de Oviedo, que aborda a formação continuada, reformas, relação universidade-escola (inclusive o distanciamento existente entre ambas) e a questão epistemológica da Pedagogia.

O trabalho seguinte, do professor Francisco Imbernón, da Universidad de Barcelona, focaliza a profissão docente inserida no contexto da globalização e da sociedade do conhecimento. Ele enfatiza quatro aspectos para os docentes assumirem as novas competências e habilidades atuais. Considera que é imperativo educar em e para uma nova ordem social, na qual é imperativa a existência de um contrato social, ambiental, cultural, ético, entre outros. Sugere, ainda, alternativas possíveis para uma nova e diferente profissão docente. 
O antepenúltimo trabalho desta seção é assinado pelo professor José Contreras Domingo, da Universidad de Barcelona. Trata da autonomia docente, abordando as implicações desta para a formação de professores. O texto é construído utilizando-se de fragmentos narrativos de uma professora italiana. Estes ilustram e ajudam o autor a desenvolver sua idéia sobre a temática.

Francisco F. García Pérez, da Universidade de Sevilla, aborda as questóes da formação de professores e as realidades educativas na perspectiva dos problemas que os professores encontram nas suas práticas cotidianas. Seu detalhado trabalho salienta vários pontos importantes, como o desajuste entre o tipo de educação que temos e as exigências do mundo atual e os múltiplos saberes docentes, finalizando com uma proposta de formação centrada nos problemas práticos da profissão docente.

A obra é finalizada com a produção do professor Miguel A. Zabalza, da Universidad de Santiago de Compostela, intitulada "El practicum y la formación del profesorado: balance y propuesta para las nuevas titulaciones". O texto perpassa o processo de "convergência”, no qual as universidades estão imersas no espaço da comunidade européia, e focaliza, entre outras questões, quatro condições básicas do modelo prático de formação de professores. Por fim, uma breve descrição dos currículos dos autores é apresentada.

Os trabalhos explicitam uma vasta bibliografia internacional sobre formação de professores, possibilitando, portanto, a divulgação de inúmeras pesquisas, produções, coletâneas e periódicos científicos na área.

O título da obra, apesar de ambicioso, revela-se pertinente ao amplo conteúdo exposto pelos diferentes autores que a compõem. $\mathrm{Na}$ primeira parte, percebe-se um esforço no sentido de contextualizar os diferentes cenários da formação docente na Inglaterra, Alemanha e regiōes espanholas. $\mathrm{Na}$ segunda parte, o esforço parece convergir para a necessidade de compartilhar projetos educativos inovadores, socializar conceitos, políticas e práticas formativas e, ainda, ampliar as discussões teóricas e metodológicas que envolvem a área de formação de professores.

O livro não está traduzido para a língua portuguesa, não aborda o amplo contexto brasileiro de formação de professores e não apresenta referências de pesquisadores brasileiros (exceto por um trabalho 
da professora Rosa Maria Torres, que foi publicado em castelhano pela Editorial Popular de Madri, no ano de 2001). No entanto, sua leitura é importante tanto para entender melhor as próprias políticas educacionais públicas brasileiras (que possuem vínculos estreitos com as dos países ibéricos), quanto para aproximar os diálogos com os pesquisadores dos centros espanhóis, no sentido de avançar nas discussões e alternativas conjuntas em âmbito internacional. 